\title{
THE STUDENTS' WRITING SKILL OF DISCUSSION TEXT AT XII GRADE OF MAN 1 INDRAGIRI HILIR
}

\author{
Maylisha.Sy, Edi Ardian, Samsul Amri \\ English Study Program \\ Universitas Islam Indragiri-Tembilahan Riau
}

\begin{abstract}
The purpose of this research is to know students' writing skill of discussion text. The design of this research was descriptive quantitative research. To reach the purpose above, the researcher was distributing test to twelfth Grade students of XII Agama 1 of MAN 1 Indragiri Hilir. The amount of them is 20 students. After collecting the data, the researcher found that their writing skill of discussion text was good. It was proven by their mean score that is 74.1. It can be concluded that students have had good skills to write discussion text. The researcher assumed that this good result can be because the students had been able to understand what the teacher explain during the teaching and learning process and they also read many texts in the library or the internet.
\end{abstract}

Keywords: Writing Skill, discussion text.

\section{INTRODUCTION}

Writing is a hard process to do. Especially for students, they need many times to exercise for mastering it. Since writing is very useful, therefore students have to carefully learn about it. Besides other skills (speaking, reading and listening) it is one of the important skills to achieve because it helps students to express their idea, and as a means to practice using grammar and vocabulary.

It cannot be denied that in every Senior High School in Indragiri Hilir, there are many texts learned by the students, such as narrative, descriptive, procedure, discussion and many else. From all the texts, discussion text is one of the texts that is mostly found in everyday life. Therefore, it is very crucial to be understood then. This text usually describes how one event can affect another event. In daily life, it can be seen in some newspapers. They sometimes describe how traffic jam produces many disadvantages. This is the kind of example of discussion text that can be seen in a newspaper of humans' daily life. Based on this fact, a discussion is one of the important 
text to be understood by the students, since it can help them understand the story of everyday life. Therefore, all senior High School students, especially in Indragiri Hilir have gotten this text information in their school, because it has been described in their school syllabus.

Students of MAN 1 Indragiri Hilir, especially twelfth Grade, are also learning this kind of text. It means they have understood about this text, at least they know the arrangement and also its purpose. Honestly, they are hoped not only knowing this kind of text, but they are also expected that they can write this kind of text. As the researcher's pre-observation at twelfth Grade of MAN 1 Indragiri Hilir that almost all of them said that this text is a little bit hard to express in written form. They are sometimes confused about how to decide which one the cause and which one the effect is. Most of them also complain that sometimes to find the idea to write discussion text is very hard.

Based on some phenomena above, the researcher feels carious how exactly their skill in writing discussion text is. Therefore, she decided to research students' writing skill of discussion text at the twelfth grade of MAN 1 Indragiri Hilir.

Based on the introduction above, the identification of this research are identified in the following:

1. Almost all of the students said that discussion text is a little bit hard to express in written form.

2. They are sometimes confused about how to decide which one the cause and which one the effect is.

3. Most of them also complain that sometimes to find the idea to write discussion text is very hard.

4. Their skill in writing this kind of discussion text is still being a question. Whether they have good or bad skills in writing.

\section{LITERATURE REVIEW}

\section{The Definition of Writing}

For students, writing is sometimes a difficult skill to be developed, because writing needs a long process, starting from collecting the idea until making the final 
draft. Therefore, having good writing is a skill. As stated by Gordon in Griffiths (2008: 244) that writing in the language classroom often seen as an extension of or support for the other skill.

Then, Harmer (2004: 3) also mentions that "writing is a skill, unlike speaking which may be acquired naturally by children through exposing the language to them, which requires some learning". It means writing is more complex, many aspects should be mastered to be competent in that skill.

In another theory, Graham and Perin in Tayib (2015: 18) describe "writing as a skill that draws on the use of strategies to accomplish a variety of goals". According to this theory that writing can help someone to achieve their goals or they can share their goals through writing. It is also in line with what Trimmer (1995: 2) says that writing is an opportunity; it allows you to express something about yourself, to explore and explain ideas, and to assess the claims of other people.

From several definitions above, it can be concluded that writing is a skill. It needs a long process and also exercises to be able to express a good idea. Besides, the ability to use grammar and choosing appropriate vocabularies are required. Because writing is not only expressing our feeling but there is knowledge in it.

\section{Method of Scoring in writing}

Hughes (1989: 91-93) which is adapted from Harris proposes writing assessments, but with some different terms. Then, the researcher used this method of scoring to asses students' skills in discussion text. Those are the explanation and the score:

Table 1 Method of Scoring

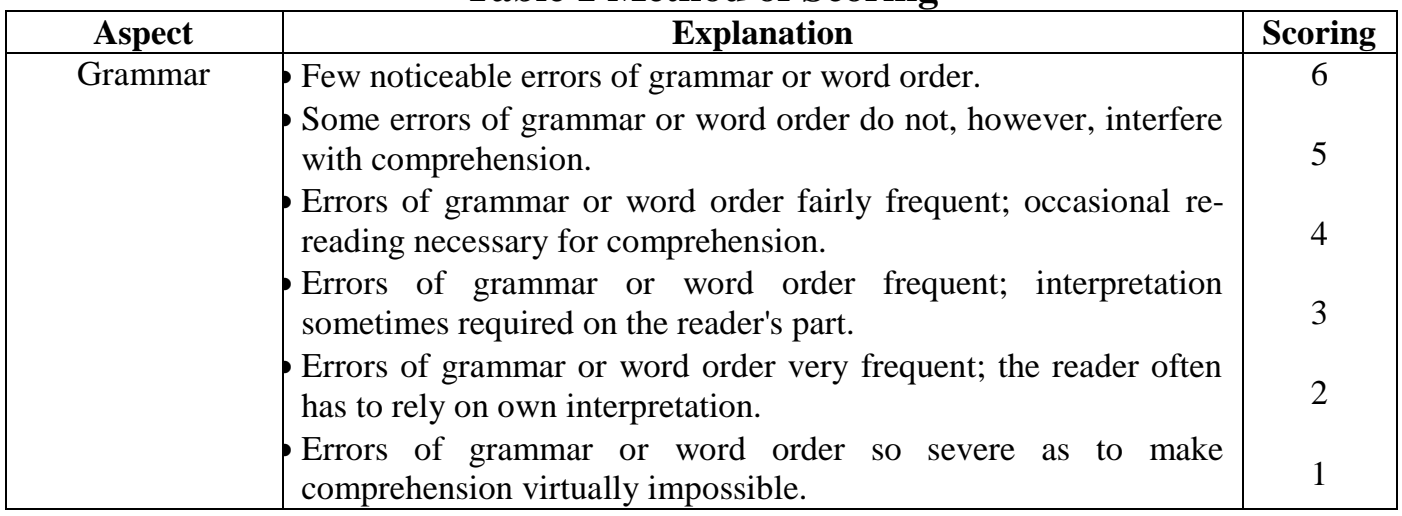




\begin{tabular}{|c|c|c|}
\hline Vocabulary & $\begin{array}{l}\text { Use of vocabulary and idiom rarely (if at all) distinguishable from } \\
\text { that of educated native writers. } \\
\text { Occasionally uses inappropriate terms or relies on } \\
\text { circumlocutions; expression of ideas hardly impaired. } \\
\text { Uses wrong or inappropriate words fairly frequently; expression } \\
\text { of ideas may be limited because of inadequate vocabulary. } \\
\text { Limited vocabulary and frequent errors hinder the expression of } \\
\text { ideas. } \\
\text { Vocabulary so limited and so frequently misused that the reader } \\
\text { must often rely on own interpretation. } \\
\text { Vocabulary limitations are so extreme as to make comprehension } \\
\text { virtually impossible. }\end{array}$ & 5 \\
\hline Mechanics & $\begin{array}{l}\text { - Few (if any) noticeable lapses in punctuation or spelling. } \\
\text { - Occasional lapses in punctuation or spelling which does not, } \\
\text { however, interfere with comprehension. } \\
\text { - Errors in punctuation or spelling fairly frequent; occasional re- } \\
\text { reading necessary for full comprehension. } \\
\text { - Frequent errors in spelling or punctuation; lead sometimes to } \\
\text { obscurity. } \\
\text { - Errors in spelling or punctuation so frequent that the reader must } \\
\text { often rely on own interpretation. } \\
\text { - Errors in spelling or punctuation so severe as to make } \\
\text { comprehension virtually impossible. }\end{array}$ & 6 \\
\hline $\begin{array}{l}\text { Fluency (Style } \\
\text { and ease of } \\
\text { communication) }\end{array}$ & $\begin{array}{l}\text { - Choice of structures and vocabulary consistently appropriate; } \\
\text { like that of educated native writer. } \\
\text { - Occasional lack of consistency in choice of structures and } \\
\text { vocabulary which does not, however, impair overall ease of } \\
\text { communication. } \\
\text { - 'Patchy', with some structures or vocabulary items noticeably } \\
\text { inappropriate to the general style. } \\
\text { - Structures or vocabulary items sometimes not only } \\
\text { inappropriate but also misused; little sense of ease of } \\
\text { communication. } \\
\text { - Communication often impaired by completely inappropriate or } \\
\text { misused structures or vocabulary items. } \\
\text { - A 'hotch-potch' of half learned misused structures and } \\
\text { vocabulary items rendering communication almost impossible. }\end{array}$ & 6 \\
\hline $\begin{array}{c}\text { Form } \\
\text { (Organization) }\end{array}$ & $\begin{array}{l}\text { - Highly organized; clear progression of ideas well linked; like } \\
\text { an educated native writer. } \\
\text { - Material well organized; links could occasionally be clearer but } \\
\text { communication not impaired. } \\
\text { - Some lack of organization; re-reading required for clarification } \\
\text { of ideas. } \\
\text { - Little of not attempt at connectivity, though the reader can } \\
\text { deduce some organization. } \\
\text { - Individual ideas may be clear, but very difficult to deduce the } \\
\text { connection between them. } \\
\text { - Lack of organization so severe that communication is seriously } \\
\text { impaired. }\end{array}$ & 6 \\
\hline
\end{tabular}




\section{Discussion Text}

Hastuti (2014: 33) states that a discussion is a factual text that explores different sides of an issue to reach an informed judgment or opinion or recommendation. Another definition is taken from Niandari and Jufri (2012: 1) that discussion text is a text which presents a problematic discourse or issue, and the aim is to present information or opinion about an issue in more than one sides: an argument for/ pros and argument against/contras. Besides, Sufyan (2015: 6) also argues that discussion text can be defined as a text that provides two contrastive arguments on the issue to inform the reader what is being discussed.

Based on some definitions above, discussion text is also the same as the cause and effect paragraph. According to Knapp (2011: 7) says that the cause and effect paragraph generally explain how one event leads to another. It can be said that this kind of paragraph shows the connection between one thing and another thing. Besides, Syfi' $i$ et al (2007:37) also state that cause and effect paragraph is a paragraph that tells what happens to the procedure a result or what will result from a certain situation or event. Nugraha (2015: 1) also explains that the cause and effect paragraph is a kind of paragraph that contains some analysis of writers about the cause and effect.

Therefore, based on several definitions above, the researcher has her conclusion that discussion text is a text which explains how one event happens and what makes it happen.

There are some stages in writing a discussion text (Sufyan, 2015: 6), they are:

1) An introductory statement of position supplying necessary background information.

2) Arguments for and against and supporting evidence.

3) A recommendation or conclusion.

The characteristics of the used language of Discussion text consist of the following points:

1) Use of present tense.

2) Use of general nouns to make statements, e.g. men, papers.

3) Use of detailed noun groups to reinforce an argument, e.g. The national treasure that is our Daintree forest can be...

4) Use of saying verbs to quote. 
5) Use of relating verbs e.g. is.

6) Use of thinking verbs expressing a personal point of view, e.g. wonder.

7) Use of factual adjectives, e.g. my last holiday.

8) Use of adjectives expressing an opinion, e.g. my horrifying adventure (Fadhilah, 2018:20)

9) Use of comparative or contrasting adjectives, e.g. boring, most significant.

10) Use of adverbs of manner, e.g. honestly, rapidly, carefully, thoroughly.

11) Use of connectives to link arguments, e.g. however, in the same way

\section{RESEARCH METHOD}

This research was conducted using descriptive quantitative research. The written test was used as an instrument in this research. Twenty respondents were asked to choose three topics to be developed in their answer sheets. This sample was taken from students of the twelfth grade of MAN 1 Indragiri Hilir. They were students of AGAMA1.

\section{FINDINGS AND DISCUSSION}

From the result of the test, it was found that students' ability in writing discussion text at grade XII of MAN 1 Tembilahan is good. It can be seen from the mean score of students' tests that is 74.1. The researcher assumed that this good result can be because the students had been able to understand what the teacher explain during the teaching and learning process and they also read many texts in the library or the internet. Besides, the researcher also assumes that they had had enough exercise writing discussion text, so it also can cause this good result.

But the researcher also found that one of the indicators in writing discussion text is not having a good result. Most of the students get a low score in grammar. It means that their understanding of language features of discussion text is still low. Even though in general their ability is good, but they need to improve their ability in grammar, especially present tense, because it is a tense used in this kind of text. 


\section{CONCLUSION}

This research was aimed at investigating students' ability in writing discussion text at the twelfth grade of MAN 1 Tembilahan. To answer this problem, the researcher used the test as the research instrument. The test was answered by the sample where the amount of them is 20 respondents. They were given an essay test that is writing a discussion text by choosing three topics to be written.

After conducting research and getting the data about it, the researcher concludes that students' ability in writing discussion text at grade XII of MAN 1 Tembilahan is good. Meaning that students have understood how to write discussion text. Besides, this good result was concluded based on the mean score of students' test results. It was 74.1. But this result is still needed improvement. Especially in grammar indicators. Most of them got a low score in grammar. So, they need to learn more about the language future of discussion text.

\section{REFERENCES}

Asmani. Jamal Ma'mur. 2013. 7 Tips Aplikasi PAKEM(Pembelajaran Akti. Kreati. Efekti. dan Arikunto, Suharsimi. 2010. Prosedur Penelitian Suatu Pendekatan Praktik. Penerbit: Rineka Cipta. Jakarta.

Fadhilah, Siti. 2018. Language Features on students Writing of Discussion Text. Published Thesis. Semarang: Walisongo State Islamic University.

Gay, LR., and Airasian, Peter. 2000. Educational Research; Competencies for Analysis and Application. New Jersey: Prentice-Hall.

Griffiths, Carol (Editor). 2008. Lessons from Good Language Learners. Cambridge: Cambridge University Press.

Harmer, Jeremy. 2004. How to Teach Writing. England: Pearson Education Limited.

Hughes, Arthur. 1989. Testing for Language Teachers. Australia: Cambridge University Press. 
Knapp, Mollie. 2011. Cause and Effect: Using Expository Writing to Problem-Solve. Trinity University: Digital Commons @ Trinity.

Maisiska, Lusi \& Rosa, Rusdi Noor. 2014. Using the Metaplan Technique in Teaching Writing a Discussion Text to Senior High School Students. Padang: Universitas Negeri Padang.

Niandari, Aulisa \& Jufri. 2012. Teaching writing A Discussion Text by Applying Assisted learning strategy (pals) at Senior High School. Padang: Universitas Negeri Padang.

Trimmer, Joseph F. 1995. Writing With a Purpose. America: Houghton Mifflin Company.

Sugiono. 2010. Metode Penelitian Pendidikan: Pendekatan Kuantitatif, Kualitatif, Dan $R \& D$. Bandung: Alfabeta.

Sufyan, Agus. 2014. His research title is “Improving Students' Discussion Text Writing through Teacher Indirect Feedback Technique. Jakarta: Syarif Hidayatullah State Islamic University.

Syafi'i, S. M., et al. 2007. The effective paragraph developments: The process of writing for a classroom setting. Pekanbaru: Lembaga Bimbingan Belajar Syaf Intensive (LBSI).

Widoyoko, Eko Putro. 2012. Teknik Penyusunan Instrumen Penelitian. Yogyakarta: Pustaka Pelajar. 